\title{
Development of Soil Site Suitability Model for Paddy Crop: A Case Study of Hydromorphic Soils in Indo-Gangetic Plain
}

\author{
Santosh Kumar ${ }^{1}$, Rajkishore Kumar ${ }^{1}$, Binod Kumar Vimal ${ }^{1}$, \\ Rakesh Kumar ${ }^{1}$, M. Haque ${ }^{2}$, Shweta Shambhvi ${ }^{1}$, Ragini Kumar ${ }^{1}$, \\ Rajeev Padbhushan ${ }^{1}$, Anamika Kumari ${ }^{3}$ and Y. K. Singh ${ }^{3 *}$ \\ ${ }^{1}$ Department of Soil Science and Agricultural Chemistry, ${ }^{2}$ Department of Agronomy, \\ ${ }^{3}$ Department of Entomology, Bihar Agricultural University, Sabour, India \\ *Corresponding author
}

\section{A B S T R A C T}

\begin{tabular}{|l|}
\hline K e y w o r d s \\
Geospatial \\
technology, \\
$\begin{array}{l}\text { Hydromorphic } \\
\text { soils, Land } \\
\text { suitability and Soil } \\
\text { profile }\end{array}$ \\
\hline Article Info \\
\hline $\begin{array}{l}\text { Accepted: } \\
\text { 15 September } 2020 \\
\text { Available Online: } \\
\text { 10 October } 2020\end{array}$ \\
\hline
\end{tabular}

\section{Introduction}

The Indo-Gangetic Plain mainly alienated with Indus-Ganga Plain and the North Indian River Plain which is account of about 2.5million $\mathrm{km}^{2}$. It encompasses fertile plain in the northern regions of the Indian subcontinent, and including most of northern and eastern India. The plain is bound to the north through Himalayas, which feed its numerous rivers and are the source of the fertile alluvium deposited across this region.
The present study was designed with an aim to develop soil site suitability model for paddy crop of hydromorphic soils under Indo-Gangetic plain. To achieve this target, the demarcation of hydromorphic soils had done based on the visual interpretation of FCC image, which was localized in Alauli $\left(\mathrm{P}_{1}\right)$, Gogri $\left(\mathrm{P}_{2}\right)$, Mansi $\left(\mathrm{P}_{3}\right)$, Khagaria $\left(\mathrm{P}_{4}\right)$ and Parbatta blocks $\left(\mathrm{P}_{5}\right)$, respectively. The results indicated that $\mathrm{P}_{1}$ and $\mathrm{P}_{5}$ were moderately suitable for paddy, whereas, and $P_{2}, P_{3}$ and $P_{4}$ were placed under marginal suitable $\left(S_{3}\right)$ on the basis of its actual land suitability class (ALSC). While, inclusion of different management practices like advocation of FYM, BGA and recommended dose of fertilizer based on soil test value, it has been placed brought under moderately suitable class $\left(\mathrm{S}_{2}\right)$ on the basis of potential land suitability class (PLSC). These results could be concluded that inculcation of suitable management options to avoid the certain limitation soil fertility constrains like organic carbon, soil wetness and topography enable to enhancement of productivity potential of paddy crop in this region.

However, crop cultivation has always been continue by without knowing the location and its specific inherent capacity including limitations of soil fertility constrains like wetness, low organic carbon, texture which enable to shows significant effect towards decline in productivity and deterioration of soil health (Gandhi and Savalia, 2014; Naidu, Ramamurthy, Challa, Hegde, \& Krishnan, 2006). Several researchers have also been evaluated soil suitability for various crops like wheat, barley, rice, maize, sugarcane, 
sunflower, potato etc., (Bhagat et al., 2009; Kumar et al., 2010, 2013) with different suitable methods or approaches through inclusion of input factors related to soil properties or the logic of suitability rating and matching procedures etc.

Hydromorphic soils is defined as a suborder of intrazonal soils, consisting of among seven great soil groups formed under poor drainage conditions like marshes, swamps, seepage areas or flats" (WSR, 2006). Despite being the predominant evidence of reduction and segregation of Iron $(\mathrm{Fe})$ stretches to temporarily permanent saturation of pores water, and its causes prolonged deficiency of oxygen (Duchaufour, 1992). The poor drainage and seepage pose to poor aeration, reduced conditions, and reduction of their biological activity, tends to hamper the outright of all soil-forming factors, which is to be essential for normal soil development. The distinctive gley horizons have been resulted from oxido-reduction process, and mottled B horizon with rusty $\mathrm{Fe}$ and manganese $(\mathrm{Mn})$ or streak because of slow diffusion process (Ponnamperuma et al., 1985 and Bhattacharya et al., 1997). The wide range of geo-statistical tools is offering newer dimensions to address problems related to site suitability analysis (Bal et al., 2018; Suryabhagavan and Balakrishnan, 2016).

The modern tools like remote sensing and Geographic information system aids to gathered voluminous information's regarding multispectral, multi- temporal and multisensor with better accuracy and offer more efficient data acquisition and their precise mapping in hydromorphic soils (Kasturirangan et al., 1996). The wide range of geo-statistical tools is offering newer dimensions to address problems related to site suitability analysis (Bal et al., 2018; Motuma et al., 2016). The GIS also offers integrated resource analysis and generating thematic maps under existing low land topography, and their validation through ground capture (Reddy et al., 2001). This technique is more acquainted towards contingent crop planning through imposing the soil suitability model (Sys et al., 1991).

Keeping the above facts in mind, development of soils site suitability model for hydromorphic areas were evaluated based on inculcation of several limiting factors. Thereby, present study was carried out for soil site suitability analysis for the promotion of paddy crops was planned in hydromorphic soils.

\section{Materials and Methods}

\section{Study area}

As per Soil Resource Mapping developed by National Bauru of Soil Survey and Land Use Planning (NBSS\& LUP) at smaller scale $(1: 250 \mathrm{~K})$, these soils were placed under recent alluvial plains with several pockets, and brought under prolonged waterlogged situations, and severally affected the growth and yield of various suitable crops in this region. its occupy the similar physiographic situation especially in the North Bihar, and existing Yazoo-type of landscapes was most predominate, severely affected by the Ganga and partly by the Kosi rivers (Fig. 1). It stretches from Teghra- Barauni in the west to Narayanpur- Thana Bihapur in the east and accompanying with approximately $500 \mathrm{Km}^{2}$. They further categorised into five suitability classes like $\mathrm{S}_{1}$ (No or only four slight limitation, placed under highly suitable), $\mathrm{S}_{2}$ (more than four slightly limitation or more than three moderate limitation under moderately suitability class), $S_{3}$ (more than three moderately limitation /one or more severe limitations under marginally suitable class), $\mathrm{N}_{1}$ (very severe limitation which can be corrected under currently not suitable) and 
$\mathrm{N}_{2}$ (very severe limitation which cannot be corrected were grasped under unsuitable class, respectively (Sys et al., 1991).

\section{Satellite images, hard ware and software}

In the present study, the multi temporal satellite images of IRS P6 LISS-III and AWiFS, Land sat 8 were used for the visual interpretation and mapping of land use and land cover pattern. Carto DEM data was also used for the delineation for elevation and slopes. Topographical sheets of the scale of 1:250000 for trace out the administrative boundary of Khagaria district and the topographical sheets of the scale of 1:50000 were used to trace out the administrative boundary of (Circle development block) C.D. block. The QGIS software (Version 3.8) was used for the visual interpretation of satellite images, digitization, digital image processing and mapping. However, topographical maps, documented soil survey reports and ancillary data were also used for reference purposes during validation of research findings.

\section{Soil samples collection and its analysis}

The collected soil samples were processed and analysed for $\mathrm{pH}$, electrical conductivity (EC), cation exchange capacity (CEC) and base saturation (BS) through standard methods, and methodology followed by Jackson (1973). The oxidizable organic carbon (OC) was determined by Walkley and Black (1934), available nitrogen (N) by alkaline $\mathrm{K}$ permanganate method (Subbiah and Asija 1956), available P by Olsen method (Olsen et al., 1954), and available K by flame photometric method methodology by Jackson (1973).

The soil samples from representative soil layers/horizons were collected, air-dried and crushed in wooden mortar and plastic and passed through $2 \mathrm{~mm}$ sieve for further laboratory analysis adopted the guideline (Soil Survey Staff, 2014), and processed for various parameter analyses. Apart from that, soil suitability, land capability and fertility evaluation of different location such as $\mathrm{P}_{1}$ (Khagarai), $\mathrm{P}_{2}$ (Parbatta), $\mathrm{P}_{3}$ (Gogri), $\mathrm{P}_{4}$ (Alauli) and $\mathrm{P}_{5}$ (Mansi), respectively have been rigorously done through procedure followed by Sys et al., (1991) and NBSS \& LUP (1994) Nagpur. The weekly data of rainfall, minimum and maximum temperature for past 10 years were collected from Meteorological Observatory, Department of Agronomy, BAU, Sabour.

\section{Results and Discussion}

The present investigation was validated through intensive study of pedological study which was conducted in localized patches of hydromorphic region. The various limitations have been identified after imposing the soil site suitability model which was laid down in this region. The various limitation like climate (c), topography (T), wetness (W), physical soil characteristic $(\mathrm{S})$, Soil fertility $(\mathrm{F})$, soil salinity and alkalinity (n) etc., have been integrated to develop the soil site suitability model in account of towards productivity potential for paddy crops. Thereby, site and weighted means of each soil's characteristics was accommodated and well depicted in table 1. Based on criteria laid down by Sys (1985) and Sehgal (1986), our objective is to prepare the list of different crops with identification of some limitation and their suitable management options in hydromorphic soils.

$\mathrm{P}_{1}$ is moderately suitable $\left(\mathrm{S}_{2}\right)$ for paddy and marginal suitable to wheat, soybean, maize and sunflower under actual land suitability class (ALSC) because of major limitations like mean temperature, wetness (drainage), physical soil characteristics (texture) and soil fertility characteristics (organic carbon and calcium carbonate) (Table 2 and 3 ). 
Table.1 Weighted mean of site and soil characterises of paddy crops in hydromorphic areas

\begin{tabular}{|c|c|c|c|c|c|c|c|c|c|c|c|c|}
\hline Pedons & $\begin{array}{l}\text { R.F } \\
(\mathbf{c m})\end{array}$ & $\begin{array}{l}\text { Mean temp } \\
\left({ }^{0} \mathrm{C}\right)\end{array}$ & $\begin{array}{l}\text { Wetness } \\
\text { (Drainage) }\end{array}$ & Texture & $\begin{array}{l}\text { Coarse } \\
\text { Vol. }(\%)\end{array}$ & $\begin{array}{l}\text { Soil } \\
\text { depth } \\
(\mathrm{cm})\end{array}$ & pH & ECe & $\begin{array}{l}\mathrm{OC} \\
\%\end{array}$ & EESP & $\begin{array}{l}\text { CCE } \\
\mathrm{C}\end{array}$ & BBS \\
\hline P1: Alouli & 1175 & 25.77 & Moderately & Clay loam & 0 & 150 & 7.38 & 1.01 & 0.59 & 70.38 & 23.14 & 95.78 \\
\hline P2: Gogri & 875 & 25.81 & Moderately & $\begin{array}{c}\text { Sandy clay } \\
\text { loam }\end{array}$ & 0 & 130 & 7.66 & 1.01 & 0.49 & 60.98 & 14.97 & 95.74 \\
\hline P3: Mansi & 875 & 25.81 & Poorly drain & Clayey & 0 & 170 & 7.55 & 1.01 & 0.54 & 70.42 & 21.27 & 95.99 \\
\hline P4: Khagaria & 875 & 25.81 & Moderately & Clay loam & 0 & 116 & 7.62 & 1.00 & 0.5 & 60.79 & 15.46 & 95.7 \\
\hline P5: Parbatta & 875 & 25.81 & Poorly drain & Clayey & 0 & 120 & 7.61 & 1.00 & 0.52 & 70.37 & 22.01 & 96.19 \\
\hline
\end{tabular}

Note: ESP (Exchangeable sodium percentage), CEC (Cation exchange capacity) and BS (Base saturation percentage)

Table. 2 Weighted rating of soil site suitability for paddy in hydromorphic areas

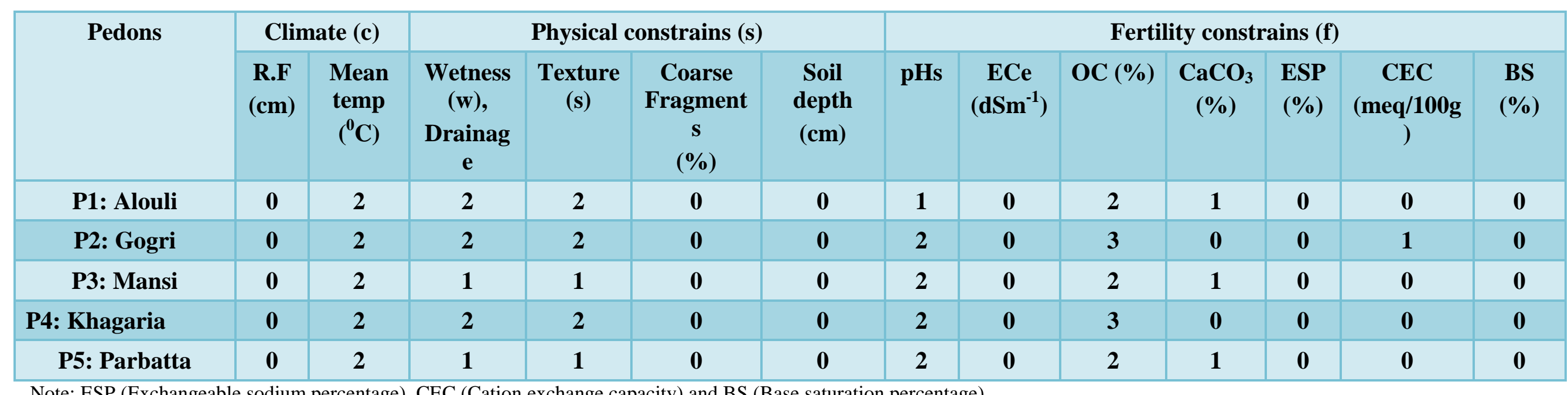

Note: ESP (Exchangeable sodium percentage), CEC (Cation exchange capacity) and BS (Base saturation percentage) 
Table.3 Overall suitability of paddy crop based on their actual and potential suitability sub-class in Hydromorphic areas

\begin{tabular}{|l|l|l|}
\hline Pedons & *ALSC & **PLSC \\
\hline P1: Alouli & S2 $(\mathrm{w}, \mathrm{s}, \mathrm{f})$ & S1 $(\mathrm{w}, \mathrm{s})$ \\
\hline P2: Gogri & S3 $(\mathrm{w}, \mathrm{s}, \mathrm{f})$ & S2 $(\mathrm{w}, \mathrm{s})$ \\
\hline P3: Mansi & S3 $(\mathrm{w}, \mathrm{s}, \mathrm{f})$ & S2 $(\mathrm{w}, \mathrm{s})$ \\
\hline P4: Khagaria & S3 $(\mathrm{w}, \mathrm{s}, \mathrm{f})$ & S2 $(\mathrm{w}, \mathrm{s})$ \\
\hline *Actual Suitability & Sub-Class (ALSC) & and **Potential Suitability Sub-Class (PLSC) \\
\hline
\end{tabular}

Fig.1 Location map of hydromophic areas in Khagaria district

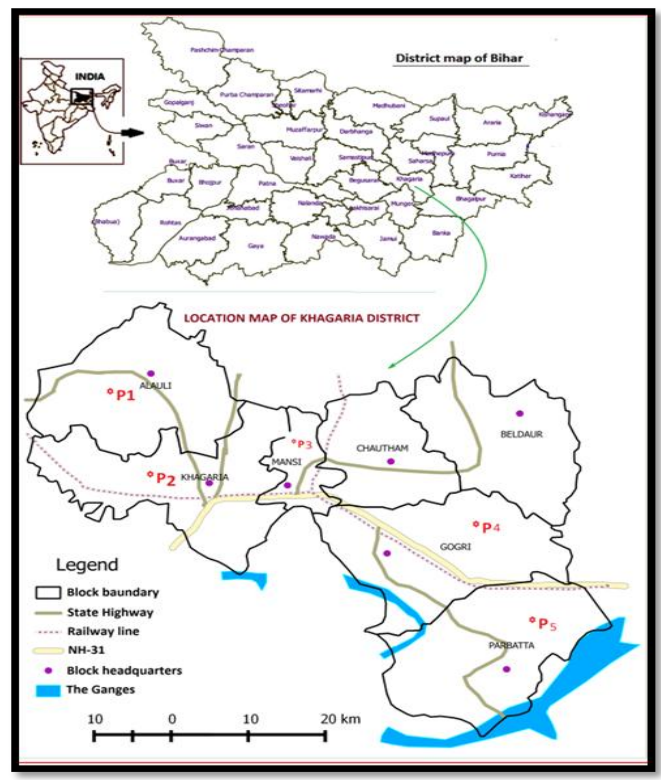

$\mathrm{P}_{2}$ and $\mathrm{P}_{4}$ have been placed under marginal suitable $\left(\mathrm{S}_{3}\right)$ for paddy, wheat, soybean, maize and sunflower, respectively as per actual land suitability class (ALSC), and inculcation of potential management practices, these pedons placed under $\mathrm{S}_{2}$ class. Similar results was also corroborated by several workers (Bhattacharyya et al., 2014; Ray et al., 2014; Tiwary et al., 2014; Srivastava et al., 2014 and Velmourougane et al., 2014), and who has been suggested that integration of crop, and suitable management factors governs the crop performance, and soil as well as land quality too.
$\mathrm{P}_{3}$ and $\mathrm{P}_{5}$ were belongs to moderately suitable class $\left(\mathrm{S}_{2}\right)$ for paddy as per actual land suitability class (ALSC), and given that, suitable management practices would be placed under $S_{1}$ class which is being considered as highly suitable $\left(\mathrm{S}_{1}\right)$. The results have been suggested that $\mathrm{P}_{1}, \mathrm{P}_{2}$ and $\mathrm{P}_{4}$ were marginally suitable for paddy except $\mathrm{P}_{1}$ (paddy placed under moderately suitable class), whereas, $\mathrm{P}_{2}$, and $\mathrm{P}_{5}$ and would be placed under moderately suitable class $\left(\mathrm{S}_{2}\right)$ as per potential land suitability class (PLSC). Similar findings were also corroborated by Leelvathi (2007) who reported that marginal suitability for growing rice crop. These 
findings are also being harmony with Sugarcane growing areas in Karnataka by Naidu and Hunsigi (2003), and they noticed that soils of Mandya and Bhadravati district belongs to moderately suitable class. Similar results were also suggested by Devi and Naidu (2016) in sugarcane growing areas in Chittoor district, Andhra Pradesh. Naidu et al., (2006) also made the suitability for major crops across India, and Mandal et al., (2008) evaluate the productivity potential for turmeric crops in Wardha district, Maharashtra, respectively.

Based on ongoing discussion, we could be concluded that paddy crops are moderately suitable $\left(\mathrm{S}_{2}\right)$ in P1 and marginal suitable (S3) in $\mathrm{P}_{2}$ and $\mathrm{P}_{4}$, respectively based on their actual land suitability class (ALSC). While consideration of potential management options, it was further placed under $S_{2}$ sub class.

However, $\mathrm{P}_{3}$ and $\mathrm{P}_{5}$ were moderately suitable $\left(\mathrm{S}_{2}\right)$ through consideration of actual land suitability sub-class (ALSC) because of different limitation like soil texture, wetness and soil fertility constraints, and induction of suitable management practices like provision of drainage facility, advocating of FYM and BGA, etc., enable to managing the sustainable agricultural productions especially for paddy crops, and potentially placed under highly suitable $\left(\mathrm{S}_{1}\right)$.

\section{Acknowledgement}

Chairman, Soil Science and Agricultural Chemistry, BAU, Sabour is acknowledged for offering laboratory facility and his valuable suggestion and inputs to enable to finalize this research work. Head of the institution is thankfully acknowledged for providing financial assistance under non plan project DR/BAU/SNP/NRM/Rabi/2017-11 and full cooperation by the Principal Investigator.

\section{References}

Bal, S. K., Choudhury, B. U., Sood, A., Mukherjee, J., \& Singh, H. (2018). Geospatial analysis for assessment of agroecological suitability of alternate crops in Indian Punjab. Indian Journal of Soil Conservation, 46(3), 283-292.

Bhattacharyya, T, Baruah, U, Gangopadhyay, S.K.and Kumar Dilip. (1997). Characterization of some Aquepts occurring in Assam valley. J Indian Soc. Soil Sci. 45: 791-796.

Bhagat, R. M., Sharda Singh, S., Sood, C., Rana, R. S., Kalia, V., Pradhan, S., et al., (2009). Land suitability analysis for cereal production in Himachal Pradesh (India) using geographical information system. Journal of the Indian Society of Remote Sensing, 37, 233-240.

Bhattacharyya $\mathrm{T}$, Chandran P, Ray SK, Mandal C, Tiwary P, Pal DK, Wani SP, Sahrawat KL (2014) Processes determining the sequestration and maintenance of carbon in soils: a synthesis of research from tropical India. In: Soil horizon. Published July 9, 2014, pp 1-16.

Devi P.A. and Naidu M.V.S., (2016). Land Evaluation for Alternate Land Use Planning of Sugarcane. Growing Soils of Chittoor District in Andhra Pradesh. Journal of the Indian Society of Soil Science, 64 (1):13-24

Duchaufour, Ph. and M. Gaffie. (1992) Methods for humus fraction types of humus and its participation in aggregate formation. Soil Science (Russian) 10:112-121.

Gandhi, G., and Savalia, S. G. (2014). Soilsite suitability evaluation for mustard in calcareous soils of Girnar toposequence in Southern Saurashtra region of Gujarat. Journal of Oilseed Brassica, 5(2), 128-133.

Jackson, M.L. (1973) Soil Chemical Analysis. 
Prentice Hall of India (Pvt.) Ltd., New Delhi.

Kasturirangan, K., Aravamundam, R., Deekshstulu, B. L., George Joseph and Chandrashekhar, M. G. (1996) Indian remote sensing satellite (IRS)-IC- The beginning of new era. Current Science 70, 495-500.

Kumar, R., Mehra, P. K., Singh, B., Jassal, H. S., and Sharma, B. D. (2010). Geostatistical and visualization analysis of crop suitability for diversification in sub-mountain area of Punjab, northwest India. Journal of Indian Society of Remote Sensing, 38, 211-226.

Kumar, S., Patel, N. R., Sarkar, A., \& Dadhwal, V. K. (2013). Geospatial approach in assessing agro-climatic suitability of soybean in rainfed agroecosystem. Journal of Indian Society of Remote Sensing, 41(3), 609-618. https://doi.org/10.1007/s12524- 0120249-9.

Leelvathi GP (2007). Genesis, classification and evaluation of soils in Yerpudu Mandal of Chittor district, Andhra Pradesh. M.Sc. Dissertation, Andhra Pradesh Agricultural University, Hyderabad.

Mandal D.K., Khule S., Mandal C., Sohan Lal, Hajare T.N. and Jagdish Prasad (2008). Soil suitability evaluation for turmeric in Wardha district of Maharashtra. Agropedology, 18 (2): 8392.

Motuma, M., Suryabhagavan, K. V., \& Balakrishnan, M. (2016). Land suitability analysis for wheat and sorghum crops in Wogdie District, South Wollo, Ethiopia, using geospatial tools. Applied Geomatics, 8, 57-66. https://doi.org/10.1007/s12518-0160168-5.

Naidu L.G.K., V. Ramamurthy, Challa O., Hegde R. and Krishnan P. (2006). Manual Soil-site suitability criteria for major crops. NBSS Publ. No. 129, NBSS \& LUP, Nagpur.: Pp. 44-46.

Naidu, L.G.K. and Hunsigi, G. (2003) Sugarcane Yield Gap Analysis, Production Trends and Fertilizer Use by Farmers in Major Sugarcane Growing Agro Climatic Zone of Karnataka Karnataka J. Agric. Sci., 16 (1): (4-12)

NBSS and LUP (1994). Proc. National meeting on soil-site suitability criteria for different crops. Feb. 7-8, 1994 held at NBSS and LUP (ICAR), New Delhi.

Olsen, S.R., Cole, C.V., Watanable, J.S. and Dean, L.A. (1954). Estimation of available phosphorus in soil by extraction with sodium bicarbonate. USDA circular No. 939.

Ponnamperuma, F. N (1985) Chemical kinetics of wetland rice soil relative to fertility. In Wetland Soils Characterization, Classification and Utilization, International Rice Research Institute (IRRI), Philippines, 71-90.

Ray SK, Bhattacharyya T, Reddy KR, Pal DK, Chandran P, Tiwary P, Mandal DK, Mandal C, Prasad J, Sarkar D, et al., (2014). Soil and land quality indicators of the indo-gangetic plains of India. Curr Sci. 107:1470-1476.

Reddy, R.S, Naidu, S.L, Ramesh Kumar LGK, Budhilal SC, Krishnan P (2001). Land resources of Medak District, Andhra Pradesh, NBSS Publ., NBSS and LUP, Nagpur. P. 791.

Sehgal, J. L. (1986) Soil site suitability evaluation for land use planning. In Introductory Pedology, Kalyani publishers, New Delhi, 1986, 174-201.

Soil Survey Staff (2014) Keys to Soil Taxonomy. 12th Edition, USDANatural Resources Conservation Service, Washington DC.

Srivastava, A., K. Velmourougane, T. Bhattatacharyya, D. Sarkar, D. K. Pal, and J. Prasad. (2014). Impacts of agroclimates and land use system on 
culturable microbial population in soils of the Indo-Gangetic plains, India. Special Issue of Current Science 107 (9):1464-69.

Subbaih, B.V. and Asija, G.L. (1956). Available rapid procedure for the estimation of available nitrogen in soils. Curr. Sci., 25, 259-260.

Sys C, Van Ranst E, Debaveye J. (1991), Land evaluation, Part 2 Methods in Land Evaluation.Agricultural Publications, 7.

Sys, C. (1985) Land Evaluation Part I, II, III State University Ghent Publication, Belgium, pp-343.

Tiwary P, Patil N G, Bhattacharyya T, Chandran P, Ray S K et al., (2014) Pedotransfer Functions: A tool for Estimating Hydraulic Properties of two major soil types of India Current
Science 107: 1431-1439.

Velmourougane, K., M. V. Venugopalan, T. Bhattacharyya, D. Sarkar, S. K. Ray, (2014). Impacts of bio-climates, cropping systems, land use and management on the cultural microbial populations at different soil depths in black soil regions of India. Special issue of Current Science 107 (9):1452-63.

Walkley, A. and Black, I.A. (1934) An examination of Degtjareff method for determining soil organic matter, and a proposed modifications of the chromic acid titration method. Soil Science 37, 29-38.

WSR. (2006). World Soil Resources Reports 103. World reference base for soil resources. Rome: 80-81.

\section{How to cite this article:}

Santosh Kumar, Rajkishore Kumar, Binod Kumar Vimal, Rakesh Kumar, M. Haque, Shweta Shambhvi, Ragini Kumar, Rajeev Padbhushan, Anamika Kumari and Singh, Y. K. 2020. Development of Soil Site Suitability Model for Paddy Crop: A Case Study of Hydromorphic Soils in Indo-Gangetic Plain. Int.J.Curr.Microbiol.App.Sci. 9(10): 1713-1720. doi: https://doi.org/10.20546/ijcmas.2020.910.207 